\title{
RED CELL GLYOXALASE II TYPE IN A JAPANESE POPULATION
}

\author{
Hiroumi Sugita and Keiichi TaKahama \\ Department of Legal Medicine, Miyazaki Medical College, \\ Miyazaki 889-16, Japan
}

\begin{abstract}
Summary The phenotypic distribution and the gene frequencies of red cell glyoxalase II were examined in a population sample of 404 Japanese using starch gel electrophoresis. The distribution was $402(99.5 \%)$ for HAGH 1 , $2(0.5 \%)$ for HAGH $2-1$ and zero $(0 \%)$ for HAGH 2 . The gene frequencies of $H A G H^{1}$ and $H A G H^{2}$ were estimated to be 0.9975 and 0.0025 , respectively. The frequency of $H A G H^{2}$ of Japanese was found to be lower than that previously reported for Micronesians.
\end{abstract}

\section{INTRODUCTION}

Glyoxalase catalyzes the irreversible conversion of methylglyoxal to D-lactic acid by two enzymatic steps in the presence of reduced glutathione (Knox, 1960). It is known that two types of enzymes, glyoxalase I and glyoxalase II [HAGH, EC 3.1.2.6], exist in erythrocytes (Cohen and Sober, 1945; Valentine and Tanaka, 1961).

Board (1980) showed that red cell glyoxalase II in the Micronesian population exhibited genetic polymorphism with common phenotypes determined by two autosomal codominant alleles, $H A G H^{1}$ and $H A G H^{2}$, using starch gel electrophoresis followed by a specific staining procedure and that the frequency of $H A G H^{2}$ was estimated to be 0.016 .

Up to the present, no report has been published concerning genetic polymorphism of this enzyme in the Japanese population. Therefore, this paper deals with the phenotypic distribution and the gene frequency of red cell glyoxalase II in Japanese.

\section{MATERIALS AND METHODS}

Blood samples were obtained from total 404 unrelated, healthy Japanese donors in Miyazaki Prefecture, southwest of Japan. Hemolysate samples were made from washed red cells by freezing and thawing.

Horizontal starch gel electrophoresis was performed in $12 \%$ starch gels at 5 
$\mathrm{V} / \mathrm{cm}$ for $19 \mathrm{hr}$ at $4^{\circ} \mathrm{C}$ using $0.661 \mathrm{~m}$ Tris-citrate, $\mathrm{pH} 8.6$ as the bridge buffer (Charlesworth, 1972) and $0.024 \mathrm{M}$ Tris-citrate, $\mathrm{pH} 8.6$ containing $0.09 \%$ EDTA as the gel buffer (Charlesworth, 1972). The staining procedure was the same as described by Board (1980).

\section{RESULTS AND DISCUSSION}

Figure I shows two different phenotypes of glyoxalase II observed among the 404 samples. Since the electrophoretic patterns obtained were comparable to those described by Board (1980), they were designated HAGH 1 and HAGH 2-1, respectively. Thus, no example of HAGH 2 could be observed. The HAGH 1 pattern consists of single band of slow electrophoretic mobility and the HAGH 2-1 pattern consists of two bands, slow moving and fast moving.

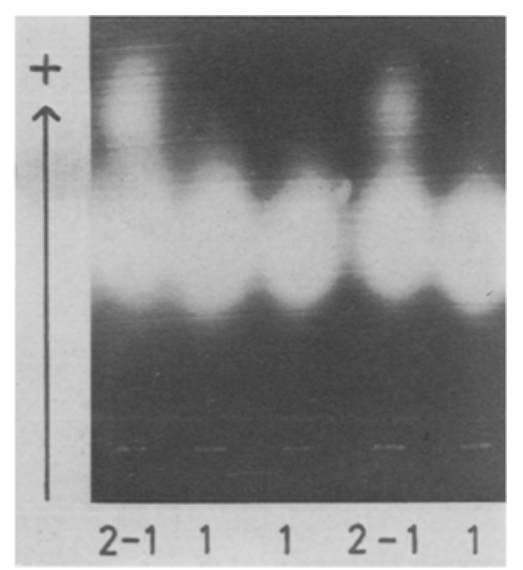

Fig. 1. Electrophoretic patterns of red cell glyoxalase II phenotypes.

Tabie 1. Distribution of glyoxalase II phenotypes and gene frequencies in Japanese and Micronesians.

\begin{tabular}{lcccccc}
\hline & \multicolumn{2}{c}{$\begin{array}{c}\text { Japanese* } \\
\text { Phenotype }\end{array}$} & & & \multicolumn{2}{c}{$\begin{array}{c}\text { Micronesians } \\
\text { (Board) }\end{array}$} \\
\cline { 5 - 6 } \cline { 5 - 6 } & Observed & Expected & & Observed & Expected \\
\hline HAGH 1 & 462 & 401.989 & & 509 & 509.14 \\
HAGH 2-1 & 2 & 1.979 & & 17 & 16.76 \\
HAGH 2 & 0 & 0.002 & & 0 & 0.14 \\
Total & 404 & 403.970 & & 526 & 526.04 \\
Gene frequencies & $H A G H^{1}=0.9975$ & & & $H A G H^{1}=0.9838$ \\
& $H A G H^{2}=0.0025$ & & & $H A G H^{2}=0.0162$ \\
\hline
\end{tabular}

* $\chi^{2}=0.0028$, d.f. $=1,0.95<\mathrm{p}<0.98$.

Jpn. J. Human Genet. 
The observed numbers of each glyoxalase II phenotype and the calculated gene frequencies are presented in Table 1. The distribution of phenotypes in the 404 donors was HAGH $1402(99.5 \%)$, HAGH $2-12(0.5 \%)$ and HAGH 2 zero $(0 \%)$, respectively, thus showing a deviation. No rare variant was found. The observed numbers of phenotypes were in good agreement with the expected ones, which were assumed according to the Hardy-Weinberg equilibrium $\left(\chi^{2}=0.0028\right.$, d.f. $=1,0.95$ $<\mathrm{p}<0.98$ ). From the data shown in this table, the gene frequencies of $H A G H^{1}$ and $H A G H^{2}$ were calculated to be 0.9975 and 0.0025 , respectively.

The frequency of $H A G H^{2}$ in Japanese is lower than that observed in Micronesians. The difference in gene frequency is statistically significant for the comparison between the two different populations $\left(\chi^{2}=9.350\right.$, d.f. $\left.=1, p<0.01\right)$.

Board (1980) stated that the family data showed the inheritance as a two allelic system without dominance. He also reported that the genetic polymorphism of glyoxalase II was extremely rare in the Asian-Pacific populations excepting Micronesians. From the data of Table 1, a low degree of polymorphism of glyoxalase II also exists in the Japanese population.

Acknowledgements We express profound thanks to Miyazaki Red Cross Blood Center for providing us with the blood samples.

\section{REFERENCES}

Board, P.G. 1980. Genetic polymorphism of human erythrocyte glyoxalase II. Am. J. Hum. Genet. 32: 690-694.

Charlesworth, D. 1972. Starch gel electrophoresis of four enzymes from human red cell: glyceraldehyde-3-phosphate dehydrogenase, fructose-aldolase, glyoxalase II, and sorbitol dehydrogenase. Ann. Hum. Genet. 35: 477-484.

Cohen, P.P., and Sober, E.K. 1945. Glyoxalase activity of erythrocytes from cancerous rats and human subjects. Cancer Res. 5: 631-632.

Knox, W.E. 1960. Glutathione coenzyme functions of GSH. Enzyme 2: 271-282.

Valentine, W.N., and Tanaka, K.R. 1961. The glyoxalase content of human erythrocytes and leukocytes. Acta Haematol. 26: 303-316. 